\title{
Cultural heritage and food identity: The pre-Hispanic salt of Zapotitlán Salinas, Mexico
}

\author{
Marie-Christine Renard ${ }^{1}$ and Humberto Thomé Ortiz ${ }^{2}$ \\ ${ }^{1}$ Departamento de Sociología Rural, Universidad Autónoma Chapingo, México \\ Carretera México-Texcoco, km. 38,5. C.P. 56230 \\ e-mail: mrenard@taurus.chapingo.mx (corresponding author) \\ ${ }^{2}$ Instituto de Ciencias Agropecuarias y Rurales, Universidad Autónoma del Estado de México \\ El Cerrillo Piedras Blancas. Toluca, Estado de México. C.P. 50090 \\ e-mail: humbertothome@hotmail.com
}

Submitted: 7 June 2015. Accepted: 27 October 2015

\begin{abstract}
Salt production in Zapotitlán de las Salinas (Puebla, Mexico) dates back to pre-Hispanic times when the Popolocas inhabiting the Tehuacán Valley paid it as tribute to the Aztecs. The technique to obtain salt has changed little over the past 500 years and know-how continues to be transmitted from generation to generation of salters (salineros). It is a resource that is deeply anchored in the identity of the inhabitants of Zapotitlán and regional cuisine. Salt has endured over the centuries as a perennial resource and constitutes a source of income for its owners. However, despite these historical and cultural factors of territorial anchorage, salters have not attained the level of organization necessary to obtain a fair value in the market. Failure to appreciate this product has led to the abandonment of a large percentage of the saltworks that once existed. This essay will analyze the socio-economic and cultural constraints that have prevented this community from attaining the level of territorial governance necessary to enhance the market value of Zapotitlán salt on the market but how, with the depletion of other economic options, its people are returning to the salt, with new strategies. Lastly, the paper will conclude with a consideration of its future potential.
\end{abstract}

KEYWORDS: LAFS; salters; territorial governance; community assets; migrants; rural tourism.

Citation / Cómo citar este artículo: Renard, Marie-Christine and Thomé Ortiz, Humberto (2016) "Cultural heritage and food identity: The pre-Hispanic salt of Zapotitlán Salinas, Mexico". Culture \& History Digital Journal, 5 (1): e004. doi: http://dx.doi.org/10.3989/chdj.2016.004.

RESUMEN: Herencia cultural y alimento identitario: la sal prehispánica de Zapotitlán Salinas, México.- La producción de sal de Zapotitlán de las Salinas (Puebla, México) se remonta a épocas prehispánicas cuando los popolocas, moradores del valle de Tehuacán, lo tributaban a los aztecas. La técnica para la obtención de la sal ha cambiado poco desde hace 500 años y el saber-hacer se sigue transmitiendo entre las generaciones de salineros. Es un recurso profundamente anclado en la identidad de los habitantes de Zapotitlán y en la gastronomía regional. Su existencia ha perdurado en el transcurso de los siglos por ser un recurso perenne y constituir una renta para sus dueños. Sin embargo, a pesar de los factores históricos y culturales de anclaje territorial, los salineros no han logrado el nivel de organización necesaria para su puesta en valor en los mercados. Esta pobre valorización del producto ha llevado al abandono de una gran parte de las salinas alguna vez existentes. Este artículo analizará los condicionantes socioeconómicos y culturales que han impedido alcanzar un grado de gobernanza territorial necesario para la puesta en valor de la sal de Zapotitlán pero como, ante el agotamiento de otras opciones económicas, se está regresando a la sal, bajo nuevos esquemas; terminará con una reflexión sobre sus potencialidades en el futuro.

PALABRAS CLAVE: SIAL; salineros; gobernanza territorial; bienes comunales; migrantes; turismo rural.

Copyright: (C) 2016 CSIC. This is an open-access article distributed under the terms of the Creative Commons Attribution License (CC BY) Spain 3.0. 


\section{INTRODUCTION}

Salt production in Zapotitlán de las Salinas (Puebla, Mexico) dates back to pre-Hispanic times when the Popolocas inhabiting the Tehuacán Valley paid it as tribute to the to the Aztecs (Mexica). The colonial period witnessed an increase in its production for use in mining and livestock, in addition to its traditional use in local cuisine, where it is highly prized. It is a Mediterranean salt obtained by evaporation in ponds from saltwater wells, geological heritage of the epoch when the sea covered the valley. The technique for obtaining salt has changed little since 500 years ago and the know-how continues to be transmitted from generation to generation of salters ( $\mathrm{sa}$ lineros). It is a resource that is deeply rooted in the identity of the inhabitants of Zapotitlán, who, despite the near disappearance of the Popolocan language, continue to take pride in their "ancestors".

Among the elements that explain the permanence of this product, saltworks (salinas) have been, in the course of history and for their owners, a constant resource and a kind of insurance to turn to the event of unanticipated contingencies and when other employment options fall through; they also constitute a source of income for their owners when they give work to others in exchange for half of the income obtained from the salt (sharecroppers).

Nonetheless, despite the historical and cultural factors of territorial anchorage and the fame this salt has in regional cuisine, the descendants of the Popolocas and owners of the saltworks have not attained the level of organization necessary to have obtain a fair value in the market: the price of salt barely pays off the investments and the work necessary to harvest it. Failure to appreciate this product has led to the abandonment of a large part of the saltworks that once existed. The primacy of competition over coordination, the intermediaries and the existence of local political bosses (caciquismo) have hindered collective strategies. In fact, some salters are opting to produce a much more profitable semi-industrial version of the salt of inferior quality mixed with vitamins for livestock, which, should this become widespread, would threaten the existence of the gastronomic salt.

On the other hand, new projects developed in recent years by non-governmental organizations, such as a tourist route centered around the core theme of salt or the production of salt-based condiments and beauty products, have helped revitalize the importance of salt to the local economy; new players have been incorporated, such as women's groups and, most importantly, migrants returning from the United States who invest their economic and social capital in these activities and in the preservation and restoration of the saltworks. Another attempt for recognition and appreciation of this pre-Hispanic salt through the obtaining of a denomination of origin was not successful.

Territorial anchorage is the result of the interaction between natural factors, cultural legacies and the ability to establish and maintain socio-economic and institutional networks (see the Introductory section of this special issue); it involves a process of collective learning situated in and oriented towards the creation of resources (Zimmermann, 1998). It implies complex relationships between nature, knowledge and specific skills developed historically by men in a particular territory, which "localize" the product and provide it with identity. The combination of these factors of territorial anchorage explain the permanence (or lack thereof) of certain identity products. Following an overview of the historical roots of salt in Zapotitlán and its form of production, this essay will examine the socio-economic and cultural constraints that have prevented this community from attaining the level of territorial governance necessary to enhance the market value for Zapotitlán salt. Lastly, the paper will conclude with a consideration of its future potential.

This research is a qualitative case study (Stake, 2000). Field information was collected in several stages, ranging from 2010 to 2015, using the ethnographic method of procedural character (Hernández et al., 2010), with which we seek to understand the elements of the social processes woven into in the production and use of pre-Hispanic salt. Toward this end, observation was made through travels to most salt production sites, as well as conducting of in-depth interviews with key informants. The sample was determined from the snowball non-probability method (Berg, 2006), in which local stakeholders closely related to the production of salt and/ or its exploitation were selected. On this basis different types of informants were obtained. We interviewed twenty seven persons in Zapotitlán, most of them in several occasions from 2010 to 2015, twelve of them tourist service providers and related to a touristic program called the Salt Route: five male tourist guides, one of them is a local historian, three of them are salters and exmigrants, two owners of an hotel (male and female), a restaurateur, three female workers of a spa (only in 2010) and the owner of a travel agency; the women were benefitting from the National Rural Women's Network (RENAMUR). We interviewed current and former authorities from the city government and the institution of Communal Property: three employees of the city government (one in charge of tourism, one in charge of statistics and one secretary), a former commissioner of Common Property, a current secretary of Common Property. As for the saltworks, we interviewed ten salters, all of them male, five young, ex-migrants, and five elders.

\section{ZAPOTITLÁN SALINAS}

Zapotitlán Salinas is a small town located at the southern end of the State of Puebla, Mexico (Figure 1). The former name of Zapotitlán is Cuthá, which means "mask" in the Popoloca language. The ancestors of this land given it this name because of the appearance that the elevation where this community is located, in profile, resembles a mask (Castellón, 2006). Its lands form part of the physiographic region of the Sierra Madre del Sur mountain range, thus its landscape is framed in an area of deep ravines, as a result of successive processes of erosion. 


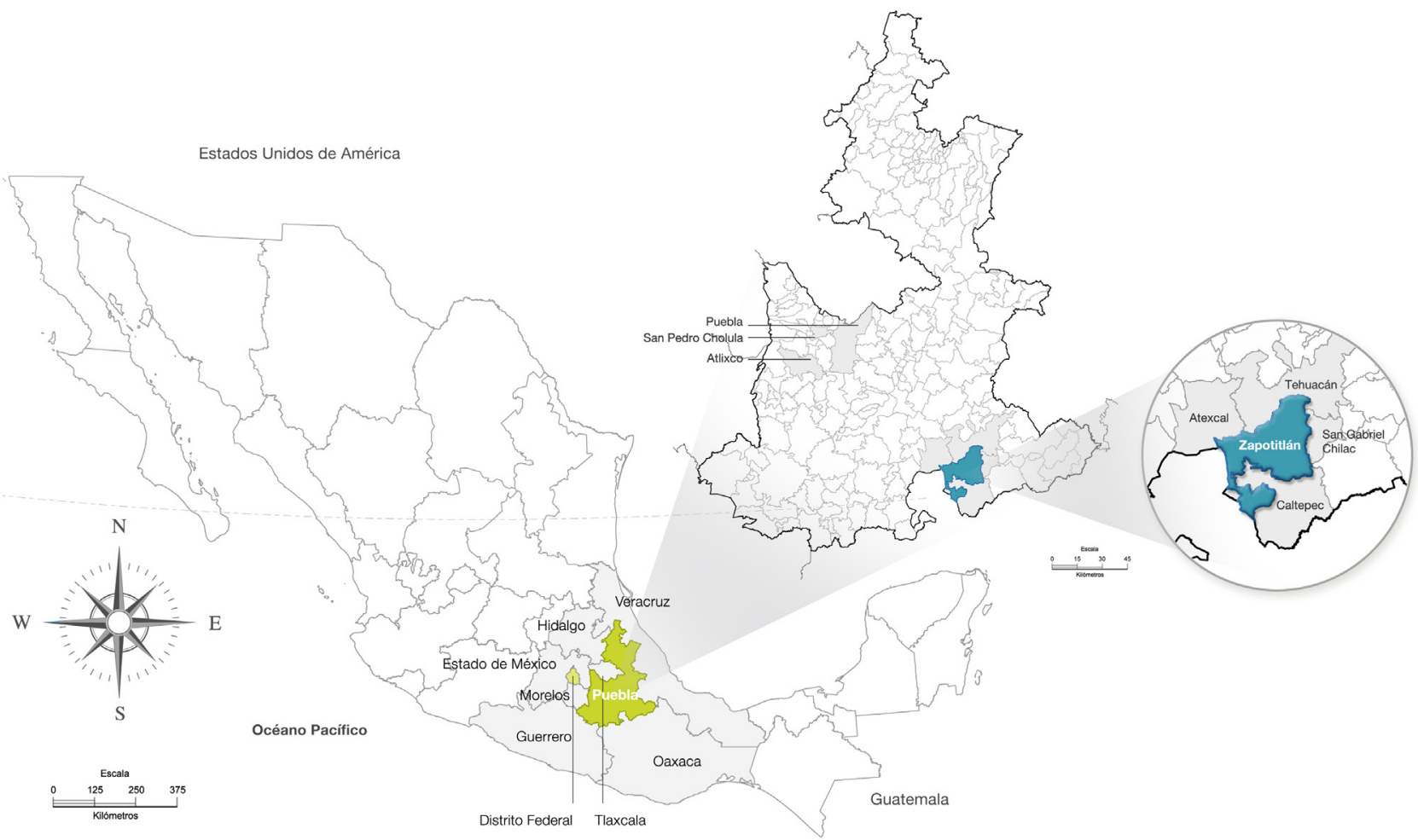

Figure 1. Mapa Zapotitlan.

Zapotitlán is nestled in the basin of the Tehuacán River, which crosses the valley populated by this community from North to South. Subsequently, these waters merge with those of the so-called Zapotitlán River which, in the section that follows is called the Salado River, due to the high concentration of salts swept by the river from the depressions of the valley, which in ancient times were Jurassic and Cretaceous seas. The soil in Zapotitlán has a considerable accumulation of calcium carbonate with minimal layers of humus, so that the development of agriculture is very limited and, since ancient times, has required irrigation systems by means of stone channels. Failing that, the best agricultural lands have been those situated on the banks of the river. The climate is characterized as warm with scarce rains in summer. Its mean annual and monthly temperature exceeds 18 degrees Celsius, resulting in characteristic vegetation consisting of low, thorny and deciduous shrubs. The presence of succulents such as biznagas, pitahayas, mezquites, palma lechuguilla, yucca and agave stands out.

Records of human occupation in the Zapotitlán Valley date from the Formative Period (200 B.C.); examples of monumental architecture on the summit of the Cuthá hill date as far back as the $14^{\text {th }}$ century, representing a human occupation of fifteen centuries (Castellón, 2006 and 2007). In different historical periods, Zapotitlán has been a strategic location from the economic and political point of view and has been influenced by the presence of resources such as salt and calcareous rocks, in addition to being a region of transit between the trade routes toward the Gulf, Oaxaca and the Mayan world (Gámiz, 1999). To the above it should be added than Zapotitlán has adverse conditions for agricultural development due to its location within the Tehuacán-Cuicatlán biosphere reserve. This affiliation, despite its potential for tourism, restricts the uses and the appropriation of natural resources for the population.

Poverty and lack of opportunity are tangible, pushing its inhabitants, mainly males, to opt for migration to the United States. It is estimated that in the last ten years more than $50 \%$ of the population has migrated (SEDESOL, 2008). This has resulted in a process of aging and feminization in the community.

Pre-Hispanic Zapotitlán salt has the peculiarity that the saltworks where it is produced are one of the few living archaeological sites that can be found in Mexico, where what remains are not only the ancient buildings of lime and stone, but a method and a mode of production dating back to ancient times, that has attracted the attention of archaeologists and ethnographers alike.

\section{ZAPOTITLÁN SALT, HISTORICAL HERITAGE}

For hundreds of years, the area formerly known as "Cuthá" has produced a traditional salt that has been part of the development of a productive and commercial skill, compensating for what nature did not give it in more fertile lands. According to Castellón (2006), archaeological references in Zapotitlán testify that this 
place was the political center of the Popoloca culture, due to the control of the saltworks. There is some dispute as to how salt was harvested in the pre-Hispanic era. According to Williams (2003: 57), evaporation patios or ponds were already being used for the production of salt, as archaeological vestiges in the area attest; however mounds averaging 3 meters in height have been found, consisting of pieces of pottery that may be associated with the production of "loaves" of salt produced by combustion and more easily transported. In contrast, Castellón (2007: 75) maintains that in pre-Hispanic times, salt was obtained by the leaching of saline soils and artificial combustion of brines boiled in clay containers - of which vestiges have been found - for the formation of the loaves of salt which were a unit of tribute and trade before and after the conquest (Castellón, 2007: 81). According to this author, the system of solar evaporation in ponds was not adopted until after the Spanish conquest, around 1525, making the practice nearly 500 years old.

During the colonial period, salt acquired more commercial importance as it was essential to the exploitation of silver and minor livestock (goats) then intensive throughout the Mixtec region. Production was restricted, for the most part, to indigenous communities. Given the importance of salt to mining, in 1580 the Crown issued regulations on its use that decreed as follows:

Spaniards, mulattos and mestizos were prohibited from inhabiting locations where salt was exploited; indigenous communities were not to be removed from salting towns, and indigenous owners were obligated to keep the saltwater pools and solar evaporation ponds on their property clean. In addition, there were severe punishments for those who adulterated the salt with lime (Sepúlveda, 2006).

This illustrates the historic possession of the "knowhow" of traditional salt production by indigenous peoples, product of racial specialization as a form of subjugation that, paradoxically, has protected the traditional and rudimentary way of producing it.

Its importance declined somewhat by the $19^{\text {th }}$ century, when mining adopted the cyanidation method, with which salt was no longer needed as a decisive supply. Despite its decline, salt continued to be produced in its traditional form insofar as it persisted as a deeply-rooted part of local markets for livestock, culinary and therapeutic purposes, which continue to have considerable demand even today, translating into their permanence in time despite economic and cultural pressures threatening autochthonous heritage.

\section{OWNERSHIP OF THE SALTWORKS, A NINETEENTH CENTURY LEGACY}

The current ownership of the saltworks has its origins in the $19^{\text {th }}$ century. Until 1850 , the lands of Cuthá belonged to the lineage of the Pacheco caciques (chieftains), whose forefather, the cacique Xopanas (or Martín Pacheco Xopanatzin), had received them, fifteen generations and centuries earlier, from the Mexica tlatoani (emperor) Moctezuma II. In 1851, the last of these chieftains, Hermenegildo Pacheco, sold the land that included the sites of the saltworks to the townspeople - who had sufficient resources to pay for them - and who would form, in 1895, an agricultural partnership for their exploitation. In 1875, this village was granted the standing of Villa de Zapotitlán. As the inhabitants of the Villa became increasingly mixed race mestizos, the indigenous population was relegated to the small villages of the surrounding area such as Los Reyes Mezontla where, to date, speakers of the Popoloca language may still be found. Around this time, the town experienced an economic upsurge due to its location in the passage for muleteers in the Camino Real, which was also the period of increased production of the saltworks. Owners belonged to a kind of elite that often resided in the neighboring city of Tehuacán and left their lands to be worked by others under foremen. The economic boom of Zapotitlán would come to an end with the Revolution in which many residents participated, never to return. In 1929, the post-revolutionary Government granted the surrounding communities half of the lands belonging to Zapotitlán, which thus went from 45 to 24 thousand hectares. ${ }^{1}$

In 1948, the community of Zapotitlán filed a request for recognition as Communal Property, under the land tenure regime reserved for indigenous peoples. ${ }^{2}$ This petition was approved in 1964, granting 24,208 hectares to 570 members of the collective. At present, according to the 2004 census, the town has 1986 recognized members of the collective ${ }^{3}$ with the right to the land and to harvest its products and fruits.

Ownership of the saltworks can be traced back to members of the agricultural partnership founded by those who bought land from the chieftain Hermenegildo Pacheco in 1851. Of these successors, some lands have been inherited by their descendants for generations, up to the present day. Others, by necessity or lack of interest, have sold them to new owners, but always within the community. The saltworks are inherited from parents to children, resulting in the fragmentation of the property over the course of generations. Despite being located in the communal lands, the successive Commissariats of Communal Property have respected the ownership of the salters. Although their owners have no official documents to protect them, no one in the town questions their rights over the saltworks. As a means of maintaining legality, it is said that what is sold is not the saltworks, located in inalienable land, but the right to work. The only regulation lies in the prohibition of transferring rights to people outside the community.

The town of Zapotitlán has 10 salt production locations, located in the ravines surrounding Cuthá hill. Each of these places has a name; Las Grandes, undoubtedly the largest saltwork site, with around 40 owners, Las Chiquitas, with 340 pairs of saltworks belonging to six owners, San Pedro, La Barranca, La Laguna, Los Castillos, Los 


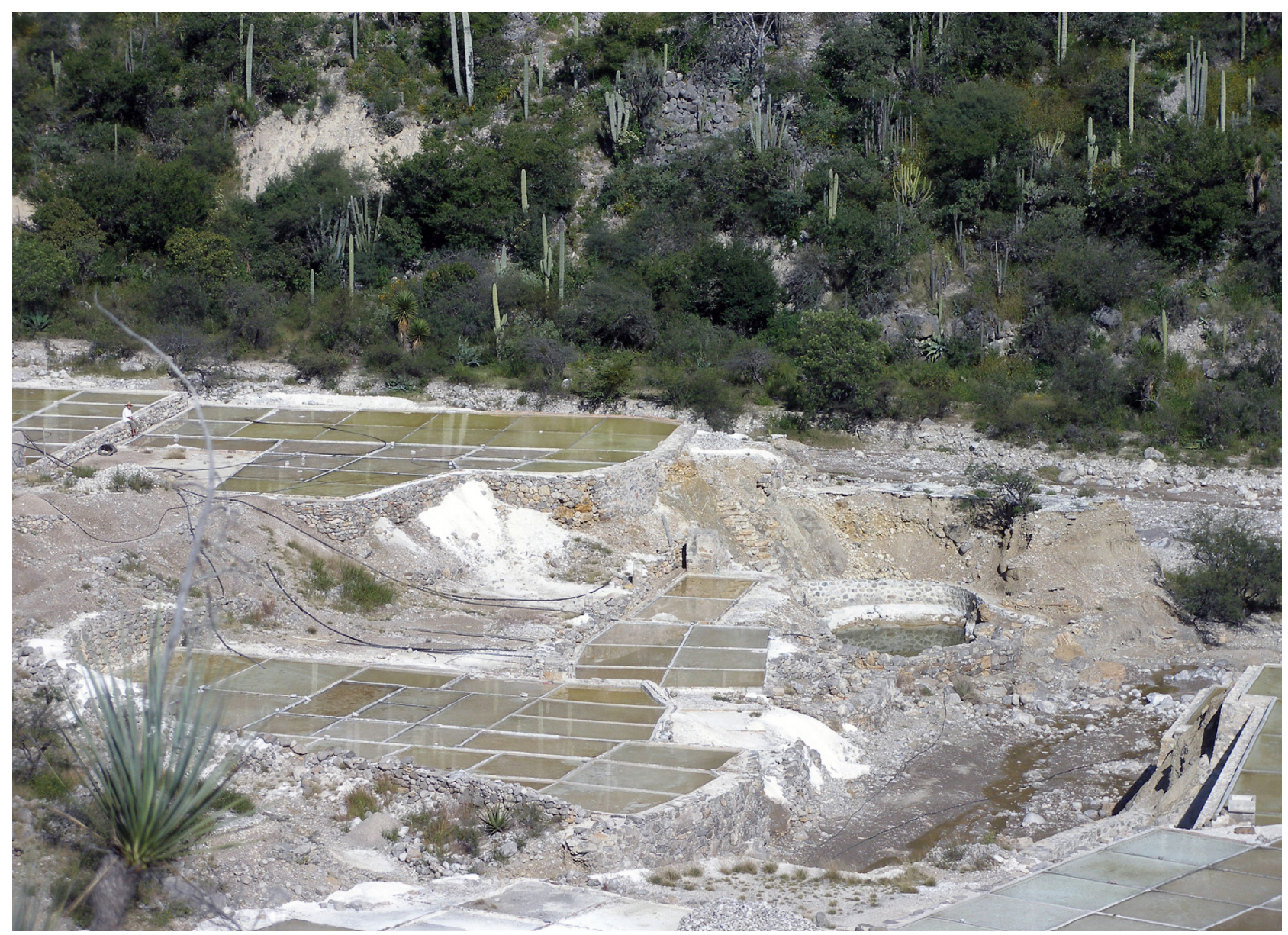

Рното 1. Saltworksite Las Grandes

Silverios, San Gabriel, Tochiga and Mihuatepec. All counted, there are approximately 63 owners for all the saltworks combined.

In the neighboring village, San Antonio Texcala, which is part of the municipality of Zapotitlán, but no longer held as communal lands but under the ejido regime, there are two sites for saltworks, La Tasa and Las Calderas, belonging to eight owners.

When the saltwork location is large, it is divided into several zones or parajes, for example, Las Jacintas in las Grandes, which all salters locate. Each saltworks site has several wells, and each well is shared among several partners. When it is time to starting filling the ponds with water, this is initiated by whomever owns the most saltworks and afterward the others follow, so there is enough water for everyone.

While the Zapotitlán saltworks constitute a heritage for the entire town, the concentration of property in the hands of a few families explains why there is a certain degree of indifference by most residents in terms of their preservation and the lack of a collective strategy to obtain a fair value of the salt on the market, despite the fact its production is the result of a know-how deeply anchored in the local culture, as we will see below.

\section{AN ANCESTRAL KNOW-HOW}

The natural history of Zapotitlán has impacted the development of salt production, because the conditions of the environment have always been an adverse for the development of agriculture. The production and marketing of salt have long been a way of generating resources for access to goods not produced locally. Zapotitlán salt is inseparably linked to the lands and salt rivers where it comes from. The flourishing of salt mining in Zapotitlán is largely due to a sophisticated monitoring of natural phenomena of concentration and saturation, evaporation, substantive phases in the process of obtaining of Mediterranean salts whose production cycle depends on natural conditions affected by rain, air, an arid environment and the availability of salt water springs (Castellón, 2006).

The production of salts in Zapotitlán is far from being a simple exploitation of natural resources, as salt exploitation has a socio-cultural anchorage expressed in the use of specialized tools, corporeal procedures and specific rituals during the entire production cycle. The work of the Zapotitlán salters is artisanal, transmitted from generation to generation and beyond the commercial logic of industrial salt refineries. Its autochthonous production methods 
are the result of empirical experience that includes components such as daily life, customs and beliefs.

Salt production in Zapotitlán has not varied considerably from five centuries ago. Among the changes that have occurred is the implementation of gasoline pumps and rubber hoses to extract the salt water from the wells in which it is stored to take it to the ponds, replacing manual labor. Until about fifty years ago, workers descended into the wells on stone stairways that can still be observed and water was carried in clay pitchers. Workers performing this dangerous task were paid by every 100 loads of water to the ponds, which was why they were called cienteros (hundreders) (Castellón, 2007). More than one died falling and drowning in a well and some of these have been named after the deceased in commemoration. ${ }^{4}$ Traditionally, pools approximately $10 \mathrm{~cm}$ deep where the salt water is left to evaporate were built forming terraces with stone floors covered with a layer of lime; given the high consumption of vegetable fuel used to produce it, this "lime kiln", manufactured by burning limestone over a wood-burning fire, has been banned and has been replaced by cement. Cement does not change the taste of the salt but it is hotter and the evaporation process is faster. However, salters report that while lime saltworks could last up to 100 years, cement saltworks break down after about 10 years, which forces them to repair them

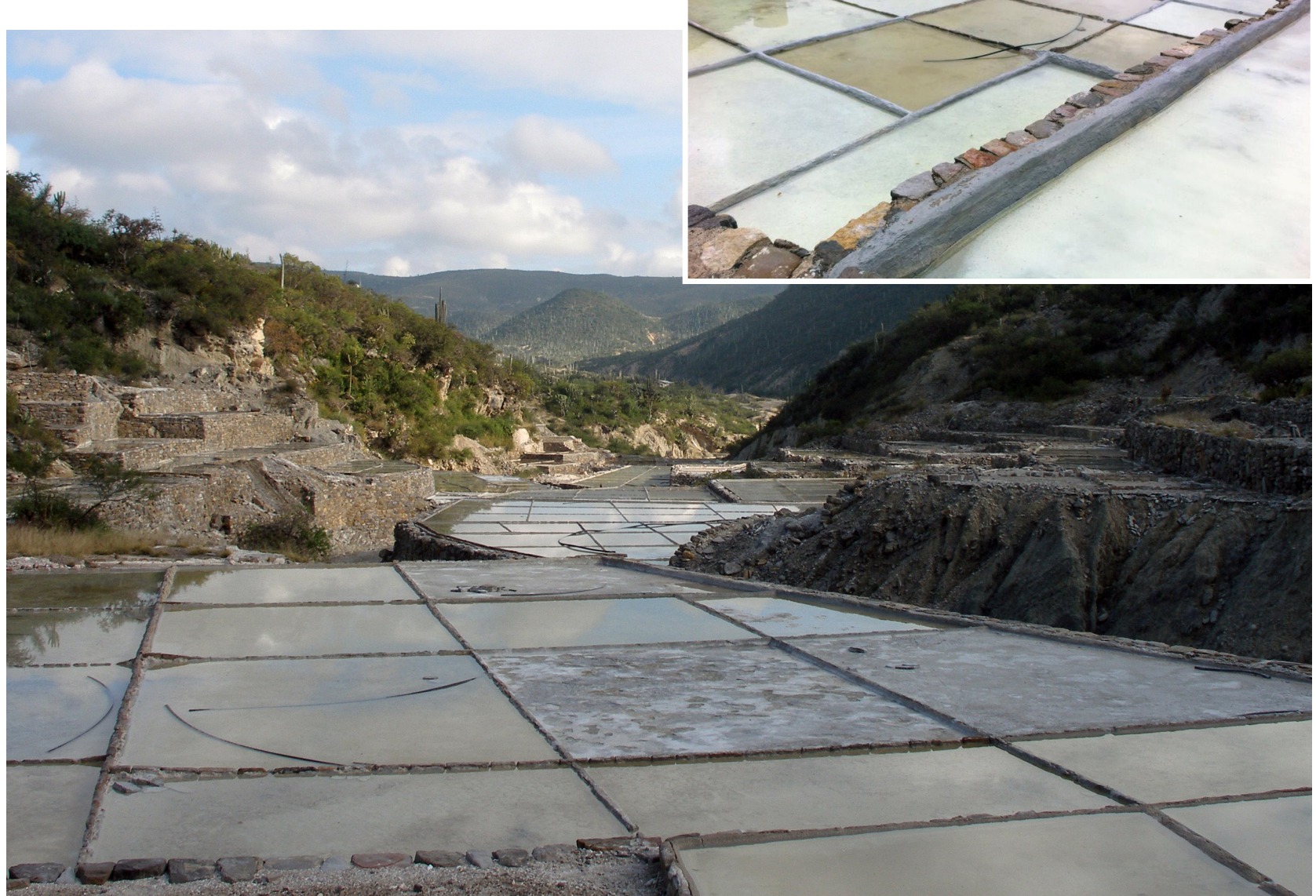

Pното 2. Ponds at saltwork. regularly; such renovation is costly due to the price of cement, which has increased markedly in recent years.

The production of this traditional salt retains a labor intensive and artisanal nature based on constant work and observation by the salter. The process begins two weeks after having initiated the repose of the saltwater, weather permitting; after this time, they proceed to wash the pools to remove all kinds of soil sediments deposited at the bottom. Saltworks are worked, registered and sold in pairs. Cleaning involves the transfer of salt from a pond or deposit to another adjacent structure, through manual labor in an uncomfortable bent position; this work requires meticulous effort to get clean the brine. Once the liquid has been decanted, a thorough cleaning of the first pond, called the "working" or "salt" pond is performed with $i x$ tle fibers, which some salters have replaced with synthetic fibers. Once the pool is cleaned, the strained water is returned to the second pond, or decanting pond, called the "warming" pond. The effectiveness of the process is cor-

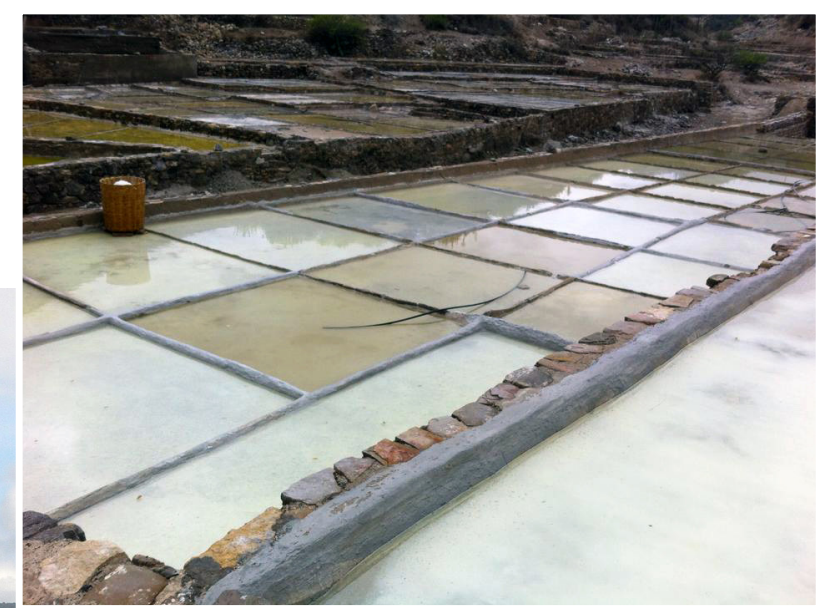


roborated by the appearance of the water which goes from turbid to more crystalline. Subsequently, the solidification process takes place which manifests itself in a short time forming a layer of salt crystals on the surface of the water. The next step is called "lowering the salt" which involves detaching the crystals on the surface by pouring water on them in order for these to sink to the bottom and in this way accelerate the process of crystallization of the underlying liquids.

Five or six weeks after initiating the process, a first harvest cycle of a salt, called tierna (tender) and intended for human consumption may be performed. Although still moist, this salt is placed in baskets, traditionally made of wicker, which act as colanders to dry it a few days and then store it in caves carved by the salters, to protect it from moisture affecting its quality and marketing. Currently few traditional caves remain much damaged and are being replaced by adobe or cement rooms. In addition, the means of transportation facilitate moving salt to the homes of the salters in the village, where the buyers go.

After the first harvest, there is still enough water in the saltworks for a second cycle. The product of this cycle will be a salt that is coarser, opaque and has a bitter taste which is intended for animal consumption.

Traditionally, the months of March, April and May are those in which salt is harvested. During the dry season in those months, salters work every day, seven days a week, and eight hours a day. In January and February there is not enough sunlight for evaporation even if it does not rain.

All this work is lost if unseasonable rains occur before the process is completed and the salt collected. In such cases the process needs to be restarted from the step of cleaning the saltworks. Over the last few years, climate change has been affecting the work of salters as cycles have become unpredictable and therefore, the salt harvest has decreased. The possibility of restarting the cycle the following year also depends on the rains that refill the wells where salt water is captured.

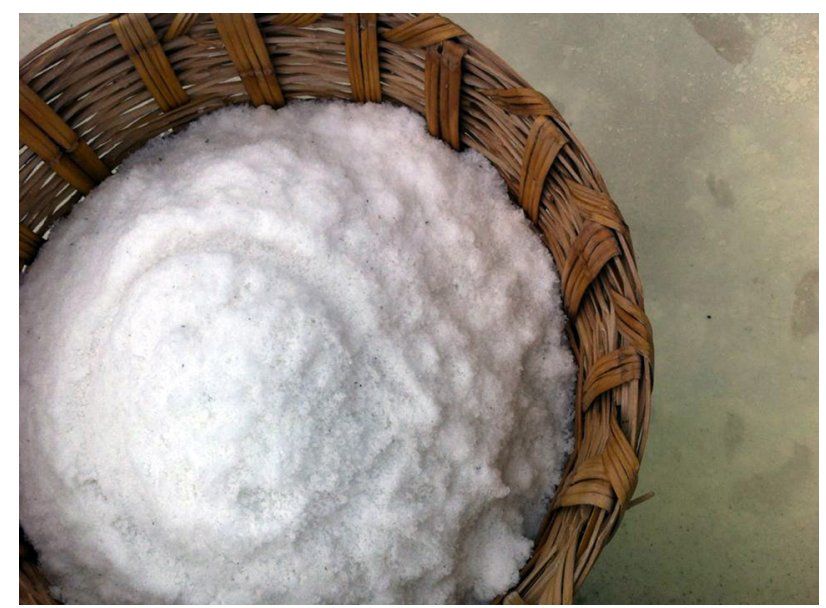

Рното 3. Salt harvest in a basket.
The seasonal concentration of activity leads to a greater demand for labor in a short time; traditionally, the owners or heads of the saltworks resorted to day laborers, mostly from other communities in the region. Knowledge and know-how to determine, for example, when the salt is ready to be harvested, is zealously held by the "masters", elders that, holding tight to their expertise, direct crews of young salters who do not possess this knowledge. Currently, only a handful of owners of numerous pairs of saltworks still hire day laborers, those who only have a few resort to family work and the sharecropping system with other men of Zapotitlán.

The permanence of ancestral know-how is also reflected in the use of non-decimal measures rooted in history and peculiar to the production of Zapotitlán salt for their measurement and their marketing. Salters measure their product in loads, liters, maquilas and bundles; edible salt is sold by liters ${ }^{5}$ in the village or in Tehuacán. The maquila is also a work tool, namely a wooden box with which salters measure salt and fill the sacks.

\section{AN ANCHOR IN REGIONAL CULTURE}

Zapotitlán tender salt is a product known for its organoleptic qualities, highly prized in regional cuisine and appreciated in the Tehuacán popular market, where salters take it to be sold. This recognition, although initially local, spread gradually towards the Mixtec region where itinerant traders carried it. It is said that the salt preserves the color of vegetables and that it is a digestive due to its high concentration of carbonates (Castellón, 2007). In addition, it continues to be an essential element for the preparation of goat meat, main ingredient of the famous moles de calderas and the feast of the slaughter of goats that takes place every year in the neighboring city of Tehuacán during the month of October. ${ }^{6}$ It is also essential for the preparation of typical dishes of the local cuisine based on products of the arid environment such as tetechas, hearts of palm, cacallas, all of them fruits of different cacti and that, along with the cuchamá worm, are being recovered in restaurants in the village.

In addition to the above, the production of salt traditionally generated a demand for products from neighboring communities such as baskets and clay pots from Los Reyes Mezontla, ixtle and maguey, used in the production process and which determined a dynamics of complementarily between the productive activities. Such interactions have been largely lost due to transformations in the production process which tend to use synthetic supplies and have replaced clay pitchers with rubber hoses and gasoline pumps.

The "salt culture" of Zapotitlán is manifested in the celebration of popular religious festivals whose function is the creation of social bond among the members of this working community: salters traditionally celebrate the Holy Cross in May in the saltwork sites. On that day which does not always coincide in all the saltworks or even necessarily on the 3rd-, a mass is celebrated and the salters and their families share a meal. This tradition 


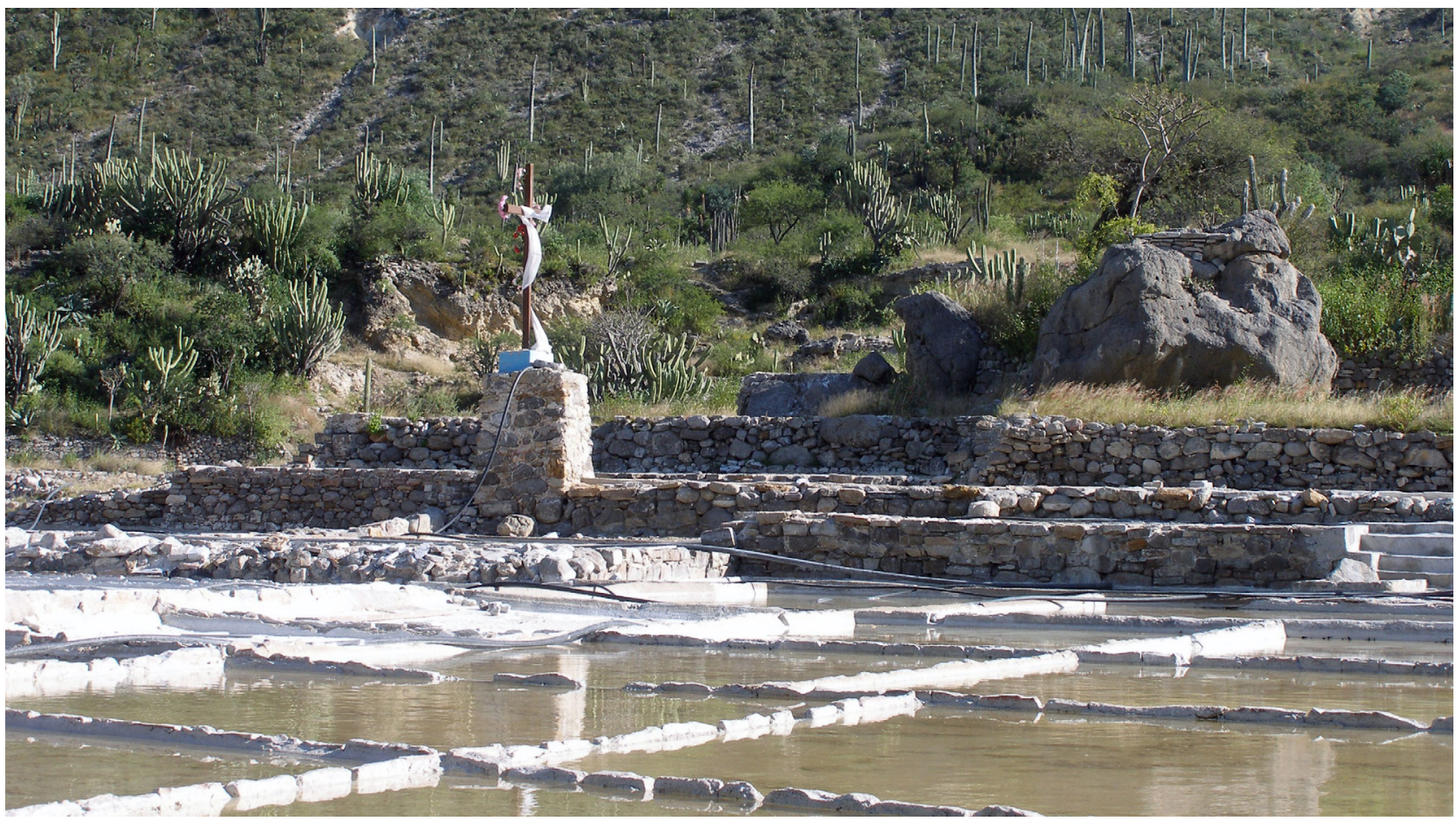

Рното 4. Sta Cruz at saltwork Las Grandes.

is often in the hands of elderly producers, and may disappear with them, as has happened already at las Chiquitas where no owner has taken up the tradition after the elder who was responsible passed away; it continues to be practiced, however, at other saltworks, among others, the largest one, las Grandes.

Village life is marked by the annual cycle of religious ceremonies, and the religious life of Zapotitlán Salinas was, for many years, closely linked to the production of salt, as part of the proceeds of its sale were devoted to the expenses of the parish celebrations in honor of the patron saint, St. Martin of Tours. Residents report that this custom lasted until the 1970s, but that, later, owners of the saltworks, perhaps due to the downturn in harvests and profits, "forgot the saints" and, despite the initial demands by the parish priest for money, they ceased to pay tribute for celebrations, which now depend on contributions from the faithful.

\section{A POORLY VALORIZED PRODUCT}

Despite this strong natural cultural and patrimonial anchorage, Zapotitlán salt is not adequately valorized economically, which explains, in part, why many saltworks have been abandoned in recent decades. The age of the salters, their lack of organization and the primacy of competition over cooperation, are among the reasons that salt is so poorly remunerated.

Individual salters go to the La Purísima market in Tehuacán on Saturdays to sell their salt. They are not always able to sell all their merchandise and thus, sometimes, re- sort to bartering, exchanging salt for fruits and vegetables. They also sell to intermediaries, some of them from the same town, others from more distant places like Atlixco, who come to their homes or to their deposits in the saltworks. These in turn market to other towns in the region and the Mixtec area. Salters do not package the salt; they sell it in plain plastic bags, with no label, which does not help differentiate the product and, thereby, its value.

In the Tehuacán market, salt is offered at 10 pesos a liter (slightly over 0.50 cents $€$ ). ${ }^{7}$ In Zapotitlán, a liter goes for 5 pesos retail, although some producers accept 2.5 or 3 pesos: even at such low prices, the brokers haggle, and if the producer asks for more, the intermediary finds someone else who will sell it to him more cheaply since the salters have not been able to organize to achieve a better and more uniform price. According to the youngest people, lower prices are often accepted by older people who settle for whatever they are paid. An attempt was made to develop a salt bank to be able to endure the days without sales and thus be able to ask for a better and more uniform price, but it was unsuccessful. A better price (10 pesos a liter) is obtained selling to tourists visiting the saltworks.

Calculating the yields is difficult since not all of the wells have the same degree of salinity and the number of annual harvests depends on climatic factors. A salter with 32 pairs of saltworks reportedly harvested four and a half tons last year (2014); at 5 pesos per liter $/ \mathrm{kg}$, he earned 22 thousand pesos. With these prices and taking into account that the salt harvest is seasonal, it is understandable that producers say that salt work is thankless and unprofitable. They mention that "before, a family lived on that, not any- 
more, because everything has gone up, except for salt." ${ }^{10}$ In addition to the above, elderly salters generally work parttime, in other words, someone else, sometimes their own son, does the work and in exchange, is paid half of the harvest; in that way owners only receive half of the proceeds from the sale of salt. And the sharecropper-sons cannot live off the salt alone either, thus they supplement it with other jobs, such as tour guides (see below), gas station attendants or construction workers, among others. The elders say that:

Young people don't like working in the saltworks any more, working under the sun, bitten by mosquitoes and before, we worked barefoot and with short pants, now they do it with boots and jeans. They're looking for other options. ${ }^{9}$

This also explains why saltworks sites have many semidestroyed ponds due to lack of maintenance; it is estimated that half the saltworks that once existed have disappeared. Salters mention the lack of water in the wells as a reason for their abandonment but, above all, a lack of maintenance. Nonetheless, on one point there is a consensus: they do not constitute a job opportunity for others: "even though they're abandoned, they can't be worked because they have owners... If you go there, the owner comes out." 10

\section{IN THE ABSENCE OF OTHER OPTIONS...}

The young sons and daughters of Zapotitlán's collective owners do not have access to the land and its products because the Communal Property census has not been updated. Locals are not allowed to collect fruits such as the tetechas from communal landholdings to be sold in restaurants either, but they do so secretly, risking reprimand. If neither the land nor the saltworks offer sufficient possibilities of survival, other options are sought. In past decades, these were the onyx quarries and, subsequently, migration. The first resulted in the destruction of saltworks, the second in their relative abandonment although currently, remittance money has helped them to be recovered.

With the opening of the highway to Tehuacán in the mid- $20^{\text {th }}$ century, onyx fever began: exploitation of this calcareous stone, abundant in the lands of Zapotitlán, was the engine of the economy of the municipality for decades, until, by the 1990s, it had been virtually depleted by overexploitation. The community was unable to regulate the extraction of this non-renewable asset; residents attribute this inability to the impossibility of coming to an agreement among the two thousand community members. In the neighboring village, San Antonio Texcala, where there are fifty members of an ejido cooperative, extraction is limited per head and per day and the townspeople continues to live off it. Onyx fever in Zapotitlán came to result in the destruction of many saltworks that were above the quarries to extract stone that was sold off at a cheaply to intermediaries from Tehuacán.

Since that time a deep division has remained in the village whose consequences persist to this day. Initially, the entire community benefited from the exploitation of the onyx thanks to the quarries of the Commissariat of Communal Property from which resources were used to build the Town Hall and other buildings. But in the 1970s, some families linked to the official party appropriated the communal positions and the common fund of the community disappeared; they forced members of the collective or their widows who had gone to live in Tehuacán to return to Zapotitlán under penalty of being stripped of their rights, and so it was that they seized the lands with onyx from a woman and distributed them among themselves. Since then, "the town has them marked" and this bad blood persists, which is not conducive to agreements for a common management.

When the onyx ran out in the 1990s, migration to the United States appeared as the solution to the lack of economic alternatives and the village was emptied of at least half of their young men. ${ }^{11}$ This explains why many of the owners of current saltworks are elderly people and is the reason for the degree of feminization of the population. New York is the principal destination for the migrant zapotitecos who have formed a community there without losing ties with their place of origin. For years, migrants, in addition to sending remittances, went back and forth between New York and Zapotitlán; several of them, when they had saved enough money, returned definitively to settle and open businesses in their village. This group of returnees has helped boost its economy and plays an important role in new strategies to enhance the value of salt, as we will see later. Over the last few years, anti-immigrant measures in the United States have slowed the flow of migration; travel between the two countries has become so difficult that many migrants no longer come to Zapotitlán and migration is ceasing to be a viable alternative. As a result, they have again turned to the saltworks. A resident reports:

A few years ago, onyx was in fashion, almost everything was sold to an Englishman for export, back then the stone put food on the table, but now it's running out and we know that we need to go back to the salt, since that's what the town has lived off of for thousands of years (Thomé, 2012).

\section{...RETURNING TO THE SALT}

In recent years the lack of economic alternatives following the depletion of the onyx quarries which were the economic engine of the region until about 20 years ago, along with the exhaustion of the option of migrating to the United States, has led to a return to the saltworks although, sometimes, under another production mode or type, such as tourism. Returning migrants play an important role in this process.

Recently, some sons and daughters of salters and returning migrants have gone back to work the salt and have invested the savings they obtained during their stay in the U.S. to restore the saltworks of their parents. Restoration implies cleaning, packing the soil and giving a smooth finish to the ponds; it takes two days and costs two to three thousand pesos per square. They have invest- 
ed despite the lack of certainty about the future ownership of the salt, in other words, without any certainty that they will inherit them some day: on the one hand, the elderly are reluctant to give saltworks up since they represent a secure income even if they are unable to work them themselves, thanks to the system of sharecropping; they also constitute insurance against future contingencies since they can sell some pairs if necessary (20 pairs were sold for 150 thousand pesos in 2015). The returnees risk losing their investment when the saltworks are sold to a third party. Moreover, the owners of the saltworks have other children, some of whom have also emigrated, and do not clarify the issue of inheritance. This uncertainty has prevented returnees from investing more in the saltworks and led some to seek support in the Commissariat of Communal Property to achieve some kind of commitment in terms of the inheritance of the saltworks from their parents.

Seeking to enhance the value of his production, the owner of a large zone of saltworks has started the intensification of production via a business model, with economically good results but with questionable social and environmental impact. For some years, this producer has ceased to produce edible salt and is exclusively dedicated to the production of mineralized salt for cattle. His saltworks are located at certain height, which gives them good sun exposure and aeration. He has modified the structure of the saltworks to accelerate the evaporation of water, the ponds have a greater surface area and depth $(30 \mathrm{~cm}$.); accelerating the process requires more water: to have more supply, he has built a wall separating his saltwater well from the adjacent saltworks, which prevents his neighbors from stocking up there, thus breaking with the ties of cooperation that have governed the use of wells for centuries. These saltworks are not worked as pairs of ponds since the heaters are in the upper part of the site and water is lowered to the saltworks located on a lower level through stone channels; the water coming from the heaters to the saltworks is not filtered since, to grind salt with vitamins, impurities are not noticeable. This producer makes one kilo-salt blocks with supplements in a workshop located in the patio of his yard in the village. With this new product, he obtains benefits much higher than edible salt sold through traditional channels and he already runs a company that employs several members of his family, and has branches and distributors in various states of the country. The salters more attached to the traditional way of doing things do not regard this favorably, stating that: "it's not a craft, its business" (Collective interview to salters, 2015). Those associated who defend the standard of living that can be achieved with the intensification of production should, however, recognize that if all producers were to follow this model, the water of the wells would be depleted. The intensification of the production of salt is not for everyone, nor is it sustainable and the entrepreneurial vision ruptures the social fabric of the community.

Other salters, however, seeing that salt for livestock is much more profitable than traditional salt, are copying the strategy and, despite the irritation this has caused the innovator, who does not want competition, also dedicate themselves to developing salt compounds and supplements for ranchers and veterinarians who provide them with supplements and purchase the final product. Even discounting the cost of the sacks and the machines needed to sew them and to make the mix, these preparations yield ten times more profit than edible salts. These recent salters, however, have not changed their saltworks — which requires a large investment - nor have they completely abandoned traditional salt production.

More recently, a new way to enhance the value of the cultural heritage of the saltworks and their product has been generated: tourism. A tourism initiative focused on women and with salt as its thematic axis was launched a few years ago and, while it has not obtained the results expected by its promoters, has been appropriated by other stakeholders in the community and has left the seed of a possible development in the future.

In 2008, the non-profit National Rural Women's Network (RENAMUR) became aware of the circumstance of women in Zapotitlán, who have been especially impacted by migratory processes: due to the absence of their husbands, they have experienced the problems inherent to family disintegration and lack of a steady and secure income. From this derives the associative character of their actions which has enabled them to more easily and effectively access different markets and benefits through collective action. Through a consulting firm specializing in the design of tourist routes, a diagnosis of the tourist possibilities of the town was carried out and it was decided that the most typical product was the pre-Hispanic salt and that it should be considered as the focal point of the project that was named Ruta de la Sal (the Salt Route). Several groups were formed (hotels, restaurants, crafts, tour guides, preparation of cosmetics etc.) and through RENAMUR they obtained resources from several Government agencies. Consultants whose work was funded by the Ministry of Agriculture, Livestock and Fisheries (SAGARPA) helped those interested in participating in the tourism project receive some training. One of the new developments generated by this process was that the population became aware that salt is its most characteristic production:

The tourism of salt sought to recover the history, traditions, homes, gastronomy, traditional medicine, handicrafts, archeological and paleontological sites and the natural environment in its entirety (Thomé, 2012).

Zapotitlán already had some experience in tourism due to its location within the Tehuacán-Cuicatlán ecological reserve and the Helia Bravo Hollis Botanical Garden, with more than 53 species of cacti, some endemic and endangered species and "elephant's foot" plants hundreds of years old. Cabins to accommodate visitors are located next to the botanical garden. The botanical garden and cabins are located on communal lands, and administered by the Commissariat of Communal Property that receives entrance fees and rents. 
Although its inclusion in the Tehuacán-Cuicatlán Biosphere Reserve entails a constraint to agricultural activities, is a tourist attraction factor that complements that offered by the community of Zapotitlán. Policies for the management of protected natural areas favor the development of sustainable tourism activities, which can result in an opportunity for the community to attract external resources. Other local attractions that were considered to be part of the salt route were the turutelas (marine fossils) in the town of San Juan Raya, some basaltic prisms, a "buried chapel" with murals, albeit vandalized, from the $18^{\text {th }}$ century, in addition to the saltworks. Young tour guides, most of them former migrants, were trained with resources from the National Commission for the Development of Indigenous Peoples (CDI). Next to the cabins in the Botanical Garden, simple facilities were built for a "Salt Spa", a project for which RENAMUR provided consultancy and financing operated by a group of ten women who were engaged in providing massages and cosmetic and therapeutic products based on pre-Hispanic salt. Initially, the group included 25 women but due to internal conflicts the group gradually became divided and dropped to less than half the original number. A corporation was formed to manage the route, i.e., the resources from government offices, an office, a web page and the relationship with tourist operators, dubbed Salytur.

Within the salt route project, a failed process had begun to obtain a protected Designation of Origin (D.O.) with the Mexican Institute of Industrial Property (IMPI), institution responsible for designations of origin in Mexico. It failed since laboratory tests found high concentrations of cyanide in some samples. Despite the fact that it has been exhaustively investigated, there is no information of anyone who has died or become ill from ingesting this product over the centuries that it has been consumed by humans and animals. Undoubtedly there were flaws in the collection of samples ${ }^{12}$ and other factors were not taken into account such as the typicality of the product, its ties with the territory or the traditional forms of production and so the petition for D.O. was denied:

In this regard it is important to add that declarations of D.O. in Mexico are somewhat ineffective and operate under unclear criteria (Barragán, 2008).

The first obstacle on the salt route was that the project, intended for women, did not include the salters, who not only were uninterested, but regarded attention to tourists as a distraction to their work with no benefit. On the contrary, they consider the presence of tourists as detrimental as they do not pay attention to where they are walking, damage and dirty the saltworks, as well as leaving garbage. This underpins a severe problem of disconnection between salters and the route, in short, a salt route without salters.

One of the weaknesses of the Salt Route was the lack of resources to operate the project. Undoubtedly this aspect indicates a structural problem of policies for the development of rural tourism, because the intervention of professional organizations such as consultancies is an un- avoidable requirement by government agencies to access specific loans and programs. Indeed, rural communities face severe problems of lack of education, so their ability to meet the specifications required by government support programs is limited. This leads to the need to operate through intermediaries with the knowledge and contacts to access the resources but at a high cost. A significant part of the budget spent was, thus, absorbed by the prestudies and the project design, leaving the always precarious operational phase somewhat unprotected. Government resources covered $100 \%$ of costs for the planning and design phase of the Salt Route but only $25 \%$ percent of the operational phase, leaving the community with the challenge of obtaining the remaining funds.

Within a few years, the project was losing legitimacy among the townspeople, who maintain that those responsible requested government funding on behalf of several applicants but never distributed the resources obtained. Thus it never really functioned as an inclusive, articulated and self-sufficient tourist route. To date, the initial project continues to function with a few hostels, a local craft shop, a group of women who produce cosmetics and scrubs based on salt and medicinal plants, another group that sells salt with seasonings, tour guides, a restaurant and a hotel belonging to returned migrants that are the most successful. Bicycles purchased for the tours were not used and a van intended to transport tourists was sold by the local head of the project. The Salt Spa was closed due to a conflict between a commissioner of Communal Property who was uninterested with the project, and the manager of the Botanical Garden was dismissed as was the woman in charge of the Spa. As of mid-2015 there was some talk of reopening the spa at a future date. But the Salt Route set an example and, taking it up, other women's groups were formed to develop cosmetics and new restaurants were opened, an onyx shop and at least one other tour operator in addition to Salytur.

The volume of tourism in Zapotitlán has increased but is centered in the Botanical Garden, which attracts domestic and foreign scientists and university groups from across the country: the garden has seven "permanent" tourist guides as well as women who sell onyx handicrafts and cosmetics based on salt. The arid landscape of this ecological reserve has been the setting for such famous films as the La ley de Herodes [Herod's Law] (1999), which was filmed near the cabins of the botanical garden and, more recently, the La Tirisia [Perpetual Sadness] (2014) that also used the saltworks as a backdrop.

Those who truly appropriated the tourism development project were returning migrants who combined the support obtained by their wives through RENAMUR with their savings to invest, one in a hotel and the other in a restaurant specializing in typical regional dishes, businesses that have prospered based on family labor. Returning migrants during their stay abroad worked, mostly, in the service sectors with which they developed skills and competencies, especially in food preparation and in business administration. They thus contributed another vision of work acquired through their migration as well as mon- 
etary capital they brought on upon their return. The restaurant operator provides meals in the dining room next to the cabins in the Botanical Garden, has participated in regional gastronomical samples and gives talks on cooking. The hotel has upgraded its facilities and multiplied its clientele. Success, however, generates competition: the brother of another migrant plan to open another hotel opposite the former with remittances he receives from his relative: "the thing is there's a lot of envy around here," says the owner. Other ex-migrants have opened, independently of the salt route project, a gas station and a few construction companies.

This group of returning migrants acts in coordination as a support network based on the exchange of customers (tourists) between hotel, restaurants and guides. The above sets the tone for returned migrants seeking work opportunities in their homeland, tourism being one of the most promising.

\section{BY WAY OF CONCLUSION}

Despite numerous ups and downs and vicissitudes, Pre-Hispanic Zapotitlán Salinas salt production has endured over the course of the centuries as a perennial, renewable, secure resource that represents a source of an income for its owners, in addition to being a cultural heritage deeply anchored and constitutive of the identity of many of its inhabitants, even if they do not earn a living from it. Salt is the product of an ancestral know-how resulting from observation by the salters of the natural and climatic conditions that have ensured the renewal of water resources and the continuity of harvests. In addition it also has a deep anchorage in culture and gastronomy not only of Zapotitlán, but of the surrounding communities of Tehuacán and the Mixtec region.

Community ties associated with the production of salt subsist through collective celebrations, the co-ownership of the wells and the orderly distribution of saltwater resources even though these have begun to disintegrate somewhat. These ties and the sustainability of the production of salt may, however, are at risk should an intensive business model become widespread. Edible salt is in danger of being displaced by the more profitable salt-based compounds for livestock.

The lesson learned by Zapotitlán Salinas salt is that strong historical, cultural and identity roots have not been sufficient to obtain a better price on the market: elements linked to the ability to build socio-economic and institutional networks involved in territorial anchorage have been lacking. In fact, a persistent element in the history of the Zapotitlán Salinas community has been their inability to develop a territorial governance that would allow them to enhance the value of their resources for the benefit of the majority of its inhabitants. Despite the advantages that the system of Communal Property constitutes, giving the community control over its inalienable territory - which has prevented actors outside the community from taking over the saltworks - the Communal Property government has been unable to regu- late collectively held property. This led, in past decades, to the overexploitation of onyx individually appropriated and cheaply sold to intermediaries outside the community and near depletion. This impedes any collective benefit to the saltworks. One of the causes of this lack of institutional capacity is the large number of community members, which makes it difficult to make decisions and consensual agreements. Another reason is the existence of political bosses (caciques) and the divisions in the community since the boom years of the onyx. Factors such as "private" property of the saltworks concentrated by a handful of owners that inhibits the general interest of other villagers for a fair price, and the aging of these seventy owners of the saltworks who continue to use sharecropping, where they are accustomed to receive what the salt gives them, without making further investment. This has prevented them from attaining a level of organization that enables them differentiate and obtain a fair value in the market for their product, even in terms of something as elementary as a minimum price agreed upon by all. Their sons and daughters, more open to innovations, have no control of the resource. Many of them are, moreover, absent, as migration has been, for decades, a way out of the lack of economic options in the municipality, and those who returned are afraid to invest their savings in saltworks that perhaps they will never will receive as inheritance if their parents decide to sell them before. "Envy" is an omnipresent factor appearing in the testimonies: which is how the inhabitants of Zapotitlán explain the primacy of competition over cooperation, lack of organization, the dispute over the support from outside the community, imitation and replication of successful initiatives. Uncertainty linked to climate change has also increased, which translates into unseasonable rains that decrease the productivity and profitability of the saltworks. The temptation to opt to cease production of edible salt and develop vitamin supplemented livestock salt that has greater demand, is considerable.

Other economic options that have invigorated the economy in past decades have been exhausted, making it imperative to find new formulas to enhance the value of the limited resources that remain. What would seem to be a problem is also an opportunity to resume working the salt in more organized way to obtain an appreciation of its value based on community initiatives and new strategies.

Among the actions required by the residents, we could mention the need to update the Communal Property census to allow more young people to have access to communal resources and to promote the renovation and working of abandoned saltworks.

At the same time, it is imperative to increase the market value of salt from Zapotitlán to differentiate it and highlight its cultural and organoleptic attributes. Faced with the impossibility, for now, of obtaining a designation of origin, other options must be sought. An improvement in the presentation of the salt is a priority, packing it in containers that identify the product and give it value rather than plain plastic bags. Ideas have been posed in this regard (jute bags, for example) but they have yet to be put 
into practice. Another possibility, already mentioned by a son of salter, is to build contacts with the Slow Food movement and thus achieve recognition of the salt and better distribution channels.

Some mention the idea of opening a specialized store of pre-Hispanic salt in the town so that they are not so reliant on intermediaries, taking advantage of tourism and products such as salt and spice blends, ointments for therapeutic use and cosmetics.

All these alternatives require, as a precondition, better organization, more cooperation and less "envy". The challenge is to achieve a degree of collective action sufficient to obtain good local territorial governance, which is easy to say but difficult to put into practice given the number of stakeholders involved: indeed, "getting two thousand community members to agree" is no easy task. It requires transparent leadership without falling into the too frequent local political bossism (caciquismo) and to overcome accumulated resentments of the past.

Tourism could be an option in line with the changes in the demographic composition of the community, as it is an inclusive activity for women, young people and older adults. It also offers the possibility of being a channel for reinvestment of remittances sent by migrants to the territory. The salt route project suffered the lack of a good diagnosis of the social dynamics within the town, of the phenomena of caciquismo and historically rooted inequalities and divisions that hindered its operation and explain the opposition or lack of interest by salters, who should have been key players. In its wake, however, some successful experiences planted the seed for other initiatives. The challenge of sustainable salt tourism would be to be aware of the cultural elements rooted in the history of the production so as not to break these down fostering greater divisions and individualism.

\section{NOTES}

1 Interviews with Mr. G.C., former commissioner of Common Property and son of the first teacher in Zapotitlán following the revolution, and Mr. G.M.P., professional tour guide, 2010.

2 The 1992 reforms of the Agrarian Reform Act under the presidency of Carlos Salinas, which marked the end of the distribution of land, were intended to place lands of the ejido regime, heritage of the Mexican Revolution, to the market. The inalienable, non-seizable and imprescriptible communal lands were, in principle, saved from these reforms, although community members could assign rights of use and enjoyment of their lands to family and neighbors (Ibarra, 1992). The highest authority is the General Community Assembly, the administration of the communal property is governed by a Commissariat of Communal Property. Communal Property does not mean that the lands are worked in common but that the communal institution is that which assigns plots to the members of the collective.

3 By comparison, the municipality of Zapotitlán has, in 2015, 8,820 inhabitants and its municipal head has around 2,700 inhabitants. The municipality includes the auxiliary boards of Los Reyes Mezontla, San Antonio Texcala, Xochitepec, Atzumba and the inspectorates Las Ventas, San Juan Raya and San Martin. Communal lands are located in Zapotitlán, San Juan Raya, Colonia San Martin and Colonia La Venta.

4 Interviews with salters, 2015
5 According to that collected in interviews, where local measurements are translated to the decimal system: 1 load $=10$ bundles; 1 bundle $=50 \mathrm{~kg}$. A maquila $=8 \mathrm{~kg}$. and 1 liter $=$ approximately $1 \mathrm{~kg}$. Castellón (2007) includes other measures: a maquila $=5$ liters; a media $=10$ maquilas; and a load $=40$ maquilas. These measurements do not coincide.

6 Since the colonial era, and still celebrated in the month of October in Tehuacán, the "slaughter of goats", animals fattened for eleven months before slaughter. In the weeks before the killing, they receive as their only food the salt from Zapotitlán saltworks, which gives them a unique flavor. Currently, 10,000 goats are slaughtered in the space of a few days, at the end of the 18th century, 80,000 were slaughtered. The slaughter of goats has become a major tourist event although it seems more and more questioned due to the cruelty of the slaughter of the animals.

$71 €=$ approximately 20 pesos; $\$ 1=17.30$ pesos. August 2015 .

8 Interview to D., young salter, Las Chiquitas.

9 Interview to Sr. L., salter and son of a salter. The informant works part time in a gas station in order to complement his income.

10 Interview to Sr. M., hotelier

11 Municipal authorities put the figure of 5,000 migrants for a population of 8,220 inhabitants of the muncipality. 2015 .

12 Information from the Tierra y Turismo S.C. Consulting Firm.

\section{REFERENCES}

Barragán, Esteban (2008) Importancia de las Indicaciones Geográficas para la protección de los productos tradicionales de México. Typescript, El Colegio de Michoacán, Zamora, México.

Berg, Sven (2006) "Snowball Sampling-I". In Encyclopedia of Statistical Sciences, 12, edited by Kotz, Samuel; Campbell B. Read; N. Balakrishnan; Brani Vidakovic and Norman L. Johnson. Wiley-Blackwell, New York: 528-532. doi: 10.1002/ 0471667196.ess2478.pub2.

Castellón Huerta, Blas Román (2006) Cuthá: El Cerro de la Máscara. Arqueología y etnicidad en el Sur de Puebla. INAH, México.

Castellón Huerta, Blas Román (2007) "Un grano de sal: aportaciones etnoarqueológicas al estudio histórico de una industria ancestral". Anuario de Historia, 1: 67-83.

Gámiz, María del Socorro (1999) Los pueblos popoloca de Tecamachalco-Quecholac. Historia, sociedad y cultura de un señorio prehispánico. $\mathrm{Ph}$. D. thesis, ENAH, México.

Hernández, Robert; Carlos Fernández and María del Pilar Baptista (2010) Metodología de la investigación. Mc Graw Hill, México.

Ibarra Mendívil, Jorge Luis (1992) “¿Hacía el fin del derecho y el corporativismo agrario?". Cuadernos Agrarios, Nueva Época, mayo-diciembre (5-6): 25-52. http://biblioteca.colson.edu.mx: $8082 /$ repositorio-digital/jspui/handle/2012/6396.

SEDESOL (2008) Municipios con muy alta y alta marginación. Programa para el desarrollo local de microrregiones, SEDESOL, México.

Sepúlveda, María Teresa (2006) "Tequitlato de Zapotitlán”. Dimensión Antropológica, 13 (37): 49-85. http://www.dimensionantropologica.inah.gob. $\mathrm{mx} / \mathrm{p}=463$.

Stake, Robert (2000) "Case Studies". In Handbook of qualitative research, edited by Norman K. Denzin and Yvonna S. Lincoln. Sage Publications, London: 435-454.

Thomé Ortiz, Humberto (2012) Un grano de sal: aportaciones del turismo agroalimentario al desarrollo rural. El caso de la sal prehispánica de Zapotitlán Salinas, Puebla, México. Ph.D. thesis, Department of Rural Sociology, Universidad Autónoma Chapingo, Chapingo, Mexico.

Williams, Eduardo (2003) La sal de la tierra. El Colegio de Michoacán, Morelia, México.

Zimmermann, Jean-Benoît (1998) "Nomadisme et ancrage territorial: propositions méthodologiques pour l'analyse des relations firmes-territoires". Revue d'Economie régionale et urbaine, 2: $211-230$ 